\title{
The Bioecology of Snail Vectors for Schitosomiasis in Brazil
}

\section{Bioecologia dos Caramujos Vetores da Esquistossomose no Brasil}

\author{
Frederico S. Barbosa \\ Constança S. Barbosa
}

\section{BARBOSA, F. S. E BARBOSA, C. S. The Bioecology of Snail Vectors for Schistosomiasis in}

Brazil. Cad. Saúde Públ., Rio de Faneiro, 10 (2): 200-209, Apr/fun, 1994.

This paper describes the ecology of two species of Biomphalaria: B.glabrata and B. straminea.

These species have been intensively studied in Brazil and in other countries since the 1950s. The

literature in this area can be broadly subdivided into three categories, linked to three distinct historical periods: 1) an accumulated store of early studies carried out in the laboratory and in the field; 2) the development of quantitative ecological models; and 3) the development of an alternative methodology for breeding snails under seminatural conditions.

Key words: Snail Ecology; Biomphalaria sp.; Schistosomiasis

\section{INTRODUCTION}

Investigations into the ecology of freshwater snails have shown that the population dynamics of these animals depend on the physical geography of a given region. Land contours, soil composition, hydrography, and climate all have a significant effect on snail population dynamics.

Further factors that effect the distribution and abundance (biogeography) of snails, and that will be addressed at a secondary level in this paper, include: the biotic and non-biotic environment, behavior, reproduction, genetics, interactions within and between species, and human influences. The relationship between the snail host and its parasites will not be discussed.

Although any physical, chemical, or biological factor can have a significant effect on population dynamics, a few factors especially those related to climate

${ }^{1}$ Escola Nacional de Saúde Pública, Fundação Oswaldo Cruz. Rua Leopoldo Bulhões, 1480, Rio de Faneiro, RF, 21041-210, Brasil.

${ }^{2}$ Centro de Pesquisas Aggeu Magalhães da Fundação Oswaldo Cruz, Campus da Universidade Federaal de Pernambuco, Recife, PE, 50670-420, Brasil. (temperature and rainfall) - are of particular importance in the natural history of planorbid snails.

In this paper, we will not discuss large-scale factors relating to physical geography, but instead will focus in specific conditions that are critical in determining the population dynamics of Biomphalaria snails in those parts of Brazil where schistosomiasis is endemic.

Above all, this study is concerned with a subject that is essentially dynamic: after they have hatched, the snails grow, reproduce, migrate, develop escape mechanisms, interact with the physical and chemical environment, and compete with their own and other species, until eventually, after a continual struggle to secure or maintain the essential components of their ecological niche, they die.

The literature in this area, and in related areas (many of with will not be mentioned in this article), is extremely extensive, and includes a significant number of useful contributions from Brazil. In this article, therefore, we will not attempt to cover all the literature, much less offer a comprehensive review of the subject. Instead, our aim is to stimulate research by raising questions and suggesting possible lines of enquiry. Furthermore, we will restrict our analysis to the two most important snail vectors of 
schistosomiasis in Brazil, Biomphalaria glabrata and B. straminea. Nonetheless, the literature cited should sufficient for any reader interested in consulting the principal sources of information in this area.

The literature on the ecology of the snail vectors of mansonian schistosomiasis can be broadly subdivided into three categories, linked to three distinct historical periods: 1 ) basic ecological research, which started with the pioneering study by Lutz (1918) and picked up steam in Brazil from the 1950s onwards; 2) the relatively recent development of a number of understanding of snail population dynamics; and 3) the very recent development of an alternative methodology, in which snail populations are bred under semi-natural conditions.

\section{BASIC ECOLOGICAL STUDIES}

The planorbid vectors of schistosomiasis possess certain peculiarities that need to be mentioned at the outset. Being freshwater organisms, they inhabit limited physical spaces, but they continue to grow throughout their life span. They are found in a wide variety of habitats, and in particular in shallow, lentic, and lotic boodies of water with weak currents. In general they are highly, or at least relatively, resistant to desiccation. They live under a narrowly defined range of conditions, in terms of temperature, salinity, and $\mathrm{pH}$ (WHO, 1957): the optimal temperature for their development is $20-26^{\circ} \mathrm{C}$, and they maintain themselves at a lower limit of $18^{\circ} \mathrm{C}$ and an upper limit of $30-32^{\circ} \mathrm{C} ; \mathrm{B}$. glabrata is inhibited at sodium chloride concentrations of 6,000 p.p.m., and the optimal $\mathrm{pH}$ for development is in the range of 7.0-8.0 (WHO, 1957).

Barbosa (1956) demonstrated that, under laboratory conditions, a period of twelve hours at freezing-point was lethal for $100 \%$ of a sample of $B$. glabrata, but that they could survive for several days at $+7^{\circ} \mathrm{C}$. The optimal temperature was $25-28^{\circ} \mathrm{C}$ the snails began to move more slowly; and two hours at $42^{\circ} \mathrm{C}$ was defined as the lethal point. High temperatures were shown to be more effective against snails immersed in water than against animals that had been estivating for 30 days: 1 hour at $45^{\circ} \mathrm{C}$ killed $93 \%$ of the former, but only $5 \%$ of the latter. It is noteworthy that $68 \%$ of the snails kept in the laboratory for 112 days remained alive after being exposed to a temperature of $45^{\circ} \mathrm{C}$ for 1 hour.

Planorbid snails are not found in all bodies of fresh water, not even in all those that might be considered capable of meeting their basic requirements. They occupy the second trophic level in the food chain, but are also capable of living saprophytically. They are hermaphrodite, albeit with a preferential tendency for heterofertilization.

These features give planorbids certain special characteristics, even though, in terms of population dynamics, they conform to the general pattern expected of freshwater animals.

It is also noteworthy that Biomphalaria snails do not maintain stable populations. Striking fluctuations occur, at times seasonally, at times on an ad hoc basis as a result of human activity, and at times for no reason that is as yet understood. Certain human activities - such as landfilling, diversion of watercourses, pollution, etc. can have a catastrophic effect on population levels.

There are two climatic factors that can cause significant disturbances to the natural rhythms of snail population dynamics: temperature and rainfall. In irrigation systems, the frequency and timing of water delivery into the channels has a clear effect on snail populations.

In temperate regions and in tropical areas at high altitudes, winter temperatures fall to a level where snail reproduction is either reduced or interrupted (Dazo et al., 1966). Extremely hot temperatures have the same effects, for example at the end of the summer, when bodies of water are low in volume and therefore susceptible to being heated to above $50^{\circ} \mathrm{C}$.

In tropical regions, the factor that has the greatest effect on freshwater snail population dynamics is rainfall. Some natural habitats dry out for a substantial part of the year, 
leading to the death of the major part of their planorbid populations, notwithstanding the ability of these animals to resist drought. However, the extremely high reproductive capacity of these animals ensures that these habitats are quickly repopulated (within no more than six weeks) once the rains have arrived.

In permanent habitats, fluctuations in the distribution, size, and density of planorbid populations occur without any apparent cause.

In Brazil's Northeast, high levels of rainfall occur during the winter along the seaboard and in the forested areas, leading to a substantial increase in the volume of snail habitats and causing floods that are sometimes sufficient to link widely separated habitats. Rivers turn into fast-flowing torrents, with the result that snails are dispersed and populations reduced. This phenomenon was extensively investigated in the 1950s (Olivier \& Barbosa, 1955a, 1955b) in Brazil's Northeast, where the wet and dry seasons are differentiated to a very high degree.

Although these pulmonare snails are aquatic, some species are known to be capable of surviving out of water for variable amounts of time. Studies of this phenomenon in Biomphalaria snails were first carried out by Barlow (1933).

Mention should also be made of the lengthy and valuable report written by Brumpt a(1941), in which the author recorded his observations on the biology of B. glabrata.

The following studies are also worth mentioning Coutinho et al. (1940) made various field observations in Pernambuco on the resistance of $B$. glabrata to desiccation. In Venezuela, Scott (1942) and Luttermoser (1946) carried out independent studies of the survival of this species in the field. The former observed that these snails could survive for eight months during the dry season prior to repopulating their habitat after the arrival of the first rains. The latter made similar observations, demonstrating that these snails could survive for two to three months on the ground in shaded areas.

The 1950s and early 1960s provided a rich crop of studies on the bioecology of planorbid snails. At least five monographs and one manual of malacology were published in this period: Rey (1956), WHO (1957), Malek (1958), Perlowagora-

Aszumlewicza (1958), Andrade (1959), and Barbosa et al. (1960).

Olivier \& Barbosa (1955a, 1955b) carried out extensive studies on the bioecology and population dynamics of two snail vectors of mansonian schistosomiasis - Biomphalaria glabrata and B. straminea - in endemic areas in Brazil's Northeast. These areas exhibit striking seasonal fluctuations, depending on the level of rainfall: the rainy season (winter) lasts from March or April to July or August, while the dry season (summer) occurs during the rest of the year. As a result, many temporary habitats dry out during the summer, even though brief showers occur from time to time. In spite of these unfavorable circumstances, however, both $B$. glabrata and B. straminea survive in these temporary habitats under certain special conditions that allow a sufficient number of snails to survive for repopulation to occur once the rainy season returns. Other habitats are permanent, in other words they contain water throughout the year. Snail collections were quantified per man/minute (Olivier \& Schneiderman, 1956). Techniques used to estimate snail populations were evaluated by Hairston et al. (1958).

Olivier \& Barbosa (1955a) observed that, in temporary habitats, the population dynamics of $B$, glabrata operate as follows: at the end of the dry season, a small number of snails are still alive on the ground, protected in some way by vegetation or the like. Under favorable conditions, they survive the dry season until the return of the rains, whereupon they reproduce rapidly and repopulate their temporary habitats. The population peaks 50-60 days after the first rains. The life span of the majority of snails is less than one year, and the maximum is 15 18 months. In permanent bodies of water, $B$. glabrata reproduces throughout the year. Fluctuations in reproductivity and in population densities have been observed, but no explanation for this phenomenon has been found. 
B. straminea is found in the Northeast of Brazil, living in similar conditions (Olivier $\&$ Barbosa, 1955b). Its life span is also short: a maximum of 15-18 months. The snail survives the long dry season in temporary habitats in a similar way to B. glabrata. The above-mentioned authors reported some evidence suggesting that $B$. straminea. This hypothesis was confirmed in the laboratory by Barbosa et al. (1985). In permanent bodies of water, B. straminea reproduces throughout the year, and exhibits some variability in its reproductive capacity.

In some areas, water temperatures are compatible with snail reproduction only for a short period, with the result that only a single generation is produced each year. In permanent bodies of water, reproduction occurs throughout the year (Olivier \& Barbosa, 1955a, 1955b).

The Biomphalaria snail vectors of schistosomiasis live in shallow water at the edges of their habitats, at a maximum depth of some 1.52 meters. This is their natural environment, which provides the food that these snails need (green algae, decaying organic matter) and is characterized by high levels of light and the presence of aquatic plants.

However, experiments with Bulinus truncates and Biomphalaria glabrata have demonstrated that these species can survive for long periods at a depth of ten meters (WHO, 1957; Jurberg et al., 1987).

There is still some uncertainly surrounding the question as to how Brazilian Biomphalaria snail spend the period of estivation. Barbosa \& Dobbin (1952) suggested that they can live through this period in mud, and there is certainly no doubt that, under adverse conditions, these snails $-B$. straminea in particular - seek out lower temperatures by moving towards and attempting to penetrate the bottom of their habitats while the mud is still soft. This phenomenon has been observed repeatedly, both in the field and in the laboratory (Barbosa, 1956; Pieri et al., 1980). In Minas Gerais, Veloso (1953) observed that B. glabrata lays its eggs in the mud on the roots of aquatic plants. Similar observations were made in Pernambuco by Barbosa (1956), who detected B. straminea eggs on the roots of Alternanthera philoscroides at a depth of $5 \mathrm{~cm}$ in the mud of a stream.

Its is known that the eggs have a very low resistance to dessication, but that eggs as well as snails are found on the roots of plants. It appears that the roots of plants offer one of the most favorable locations for the survival of planorbids during the dry season (Barbosa \& Olivier, 1958).

There are also other types of locations in which the snails can survive out of water. Any location in which the snail is protected from direct sunlight and predatory animals (birds and rats, mainly) - for example any type of vegetation, or a variety of items made available by human activity (tiles, bricks, tree trunks, pieces of wood, etc.) - may give sufficient protection during the dry season. Locations of this type were observed and described in field studies carried out in the State of Pernambuco (Olivier \& Barbosa, 1955a, 1955b; Barbosa, 1956, 1962; Barbosa \& Olivier, 1958).

Both B. glabrata and B. straminea have been found buried in mud at certain depths. The possibility cannot be ruled out that these findings were coincidental and nonsignificant. However, the buried snails were always found in small numbers and at a depth that never exceeded 10cm (Barbosa, 1956).

Paraense (1955) explained the recolonization by $B$. glabrata of habitats treated with molluscides, in Minas Gerais, by noting that living snails had been found buried in mud at a depth of $40 \mathrm{~cm}$.

Extensive observations by Olivier \& Barbosa (1955a, 1955b) indicate that the snails do not necessarily enter the ground in order to escape the effects of the appear to be bioecological in the sense of being part of the life cycle of planorbid snails. These mollusks cannot be considered natural diggers on a par with other animals that are physically equipped to bury themselves as a means of escape or protection.

Planorbid snails can also be buried passively by the hooves of heavy animals, such as cattle and horses, or trapped in cracks in the ground. A number of laboratory 
studies have elucidated some of the conditions that characterize snail estivation.

Olivier \& Barbosa (1954) demonstrated that when B. glabrata is submitted to different relative levels of humidity, weight loss and death depend on the degree of humidity within the container. This suggests that the snails need high levels of humidity to survive.

The resistant of these snails to desiccation varies within and between species. Barbosa $\&$ Olivier (1958) observed that B. glabrata from Salvador capacity to survive out of water than snails of the same species from Paulista, Pernambuco. Snails (B. glabrata) from three different locations in Salvador and one in Paulista were kept out of water in clay pots, at a relative humidity of $90-96 \%$. This experiment cleary demonstrated that the snails from Pernambuco were more resistant. Interestingly, the Bahian snails came from permanent habitats, while the animals from Pernambuco were taken from areas that were taken from areas that were subject to seasonal desiccation. There is evidence to suggest that resistance to drought may represent a genetic pre-adaptation to environmental conditions.

Paraense (1957) described the presence of a set of six lamellae in the opening of the shell of $B$. glabrata. The presence of lamellae were found to be associated with a tendency to leave the water. These observations have since been confirmed by a number of authors, suggesting that the phenomenon may be linked to a survival mechanism enabling the snails to endure adverse environmental conditions. For references, see Barbosa (1989).

Field studies on the population dynamics of Biomphalaria snails have demonstrated the instability of snails populations, over and above the variations associated with seasonal, climatic, and ecological factors, as mentioned above. Obviously, the snail populations stop growing during estivation, and this phenomenon forms part of the planorbid life cycle in certain regions. In snails exhibiting immature infection, the sporocysts of $S$. mansoni also display reduced activity during the dry phase (Barbosa \& Barbosa, 1958).

A recent monograph, with an extensive bibliography (Pieri, 1985), describes various aspects of the bioecology of B. glabrata in the Northeast of Brazil.

\section{QUANTITATIVE MODELS}

The life cycle of these snails has been studies quantitatively. Notwithstanding the variable conditions under which these studies have been carried out, our knowledge of snail population dynamics has progressed significantly as a result of some very valuable investigations. However, it is difficult to compare these studies, due to the fact that they were carried out under a variety of conditions.

The principal characteristics of a population of planorbid snails are: density, reproduction mortally, dispersion, and biotic potential. Of these characteristics, rate of reproduction and age-related mortality are used to construct life tables.

In the case of these snails, the first step is to determine the age of the animals. This can be done indirectly using selected standards, or - following a more recent method - by carrying out laboratory tests to establish the relationship between age and maximum diameter (Barbosa et al., 1992).

In general, age has been estimated from the relationship between the number of spirals and the maximum diameter of the snails. This method has been used by various authors, including Scott (1940) and Barbosa \& Muench (1951). Silva (1951), on the other hand, preferred to use the radius of the snails in his measurements. The majority of authors have used the maximum diameter of the shell (Barbosa et al., 1992)

It is known that, in the laboratory, the growth of individual snails occurs, linearly and continuously, in two phases, until death. The beginning of the second phase (in which growth is slower) concides with sexual maturity (Figure 1). The slope of the growth curve corresponds to the growth displayed by the population as a whole, i.e., the mean rate of growth per individual snail in a given time (Barbosa \& Silva, 1951). 
FIGURE 1. Growth of B. glabrata in Laboratory. Sample of 14 Speciments, Recife, PE. According to Silva (1951).

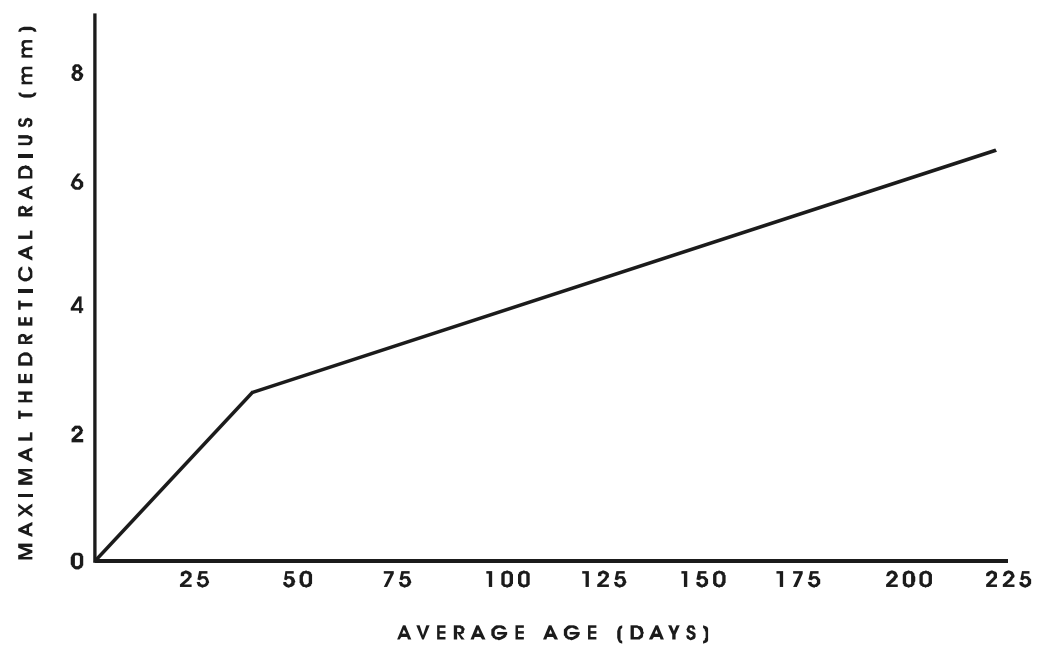

The maximum level of growth in a population represents its growth potential and is known as "the intrinsic rate of natural increase", represented by the letter r. A stable population results from a balance between the limits imposed by the environment and the inherent growth potential of the population.

In populations in the stationary phase of growth in a non-limited environment, $\mathbf{r}$ can be calculated using the following equation:

$r=\frac{d N}{d t N}$

in which $\mathbf{N}=$ number of snail, and $\mathbf{d} \mathbf{N}=$ numerical changes occurring in a given time dt.

The exponential rate of growth can also be termed "the innate capacity for growth", i.e., the maximum biological capacity for reproduction and growth in a population.

To obtain age-related rates of reproduction it is necessary to measure the maximum diameter of the snails. These measurement techniques are difficult to execute, and are subject to the human error of the observer, as well as to inaccuracies associated with the techniques themselves. It is well known, for example, that handling new-born and young snails is problematical. All of this adds to the difficulty in comparing results obtained by different researchers.

When age-related mortality rates are obtained directly by searching for dead snails (shells), the same problems arise as described above. Dead snails that are relatively small in diameter will often escape the eye of the observer, and they frequently disintegrate in the period between two sample collections. However, the number of adult snails in each age group, in a given collection, is taken as the reference for subsequent collections. Using the data obtained on rates of growth, an estimate can be made of the losses that have occurred in the period between the first and succeeding collection. The following exponential equation is used to calculate the daily mortality rate: $1 x=e^{x d}$, in which $l x$ is the proportion of snails surviving to age $\mathbf{x}, \mathbf{x}$ $=$ the number of days between two collections, and $\mathbf{d}=$ the daily mortality rate.

Life tables can be constructed from these data, and computer programs can be used to facilitate quantitative representation of these calculations (see Ricklefs, 1984, or other manuals on animal demography).

Models for the study of planorbid population dynamics have been described by various authors (Webbe, 1965: Dazo et al., 
1966; Jobin \& Milchelson, 1967; Jordan \& Webbe, 1969; Thomas \& Banjamin, 1974; Sturrock \&Sturrock, 1970; Sturrock, 1973; Loureau \& Baluku, 1987; Woolhouse, 1989).

\section{ALTERNATIVE MODEL}

An alternative methodology for breeding, Biomphalaria snails has been developed, using artificial channels four meters in length, a controlled environment and continually renewed water from a natural source (Barbosa et al., 1983, 1992). This method has made it possible to study the population dynamics of these snails, and offers obvious advantages when compared to traditional laboratory methods.

Populations that are expanding contain a relatively high number of young animals. Conversely, a high level of older animals indicates that a population is dying out.

Figure 2 shows how this phenomenon occurs in a seminatural environment, in an open system with continual water renewal (Barbosa et al., 1992). These conditions allow a population to reach the stationary level $\mathbf{r}$ in a period of 60-80 weeks. When a population reaches this upper growth limit, also known as "saturation level" or "carrying capacity", it begins to exhibit periodic fluctuations, either up or down. These fluctuations are due to two types of factors: intrinsic and extrinsic. The latter are those that are associated with environmental variations arising from climate or other ecological conditions.

Figure 2 shows a population of $B$. glabrata in which growth is limited by intrinsic factors alone, since extrinsic factors have been eliminated by the nature of the experimental method used. In this instance, the fluctuations are due to the biotic potential of each population as it interacts within is own species. This characteristic is constant in any given population, suggesting that genetic variations may determine the demographic characteristics of these snails (Loureau \& Baluku, 1987).

The three populations studied by Barbosa et al. (1992), exhibited a "snail crude density" that was significantly different in each population: the two strains of $B$. straminea displayed clear advantages over $B$. glabrata when bred under identical conditions, especially the R3 strain, which has been used in investigations on snail biological competition in the Northeast of Brazil (Barbosa et al., 1993).

FIGURE 2. B. glabrata: Population Growth and Size Distribution, under Seminatural Conditions. According to Barbosa et al., (1992)

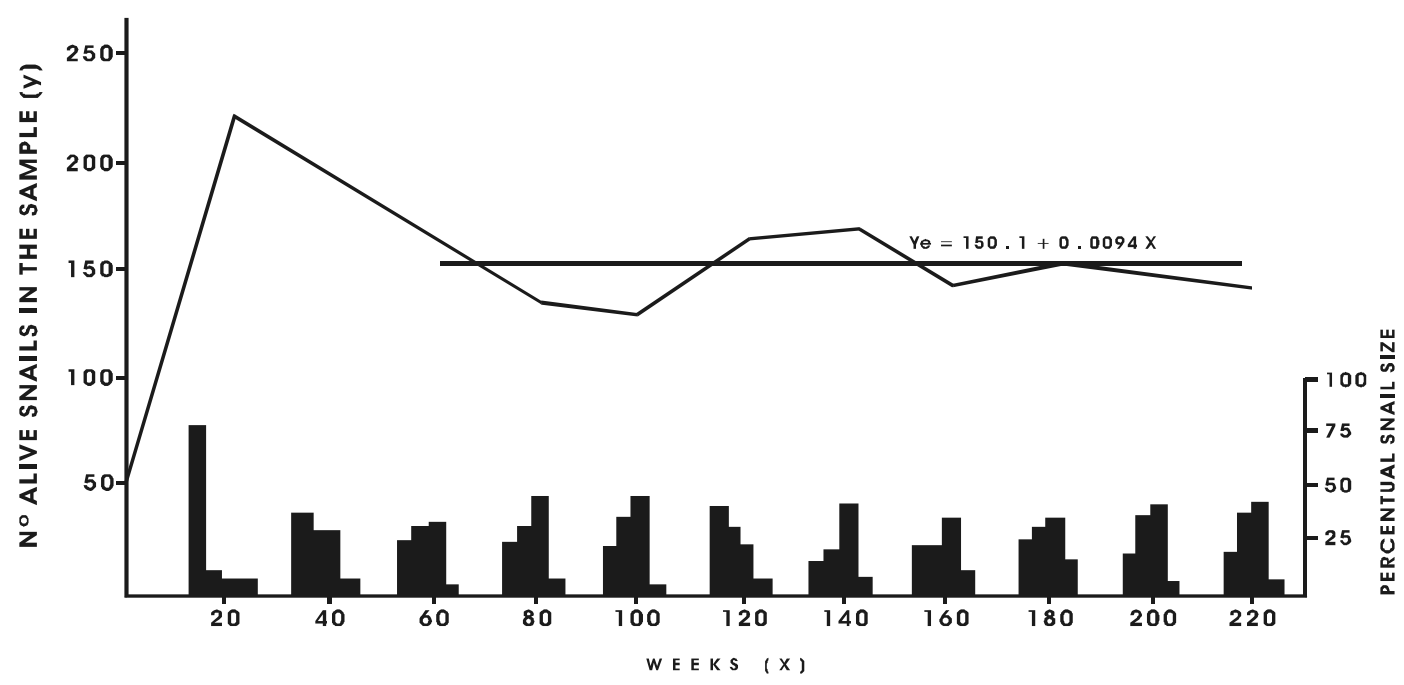




\section{RESUMO}

BARBOSA, F. S. \& BARBOSA, C. S.

Bioecologia dos Caramujos Vetores da

Esquistossomose no Brasil. Cad. Saúde

Públ., Rio de Janeiro, 10 (2): 200-209, abr/jun, 1994.

Aspectos ecológicos de duas espécies brasileiras de Biomphalaria, transmissoras da esquistossomose mansônica, são discutidos no presente artigo. B. glabrata e $a B$. straminea têm sido intensamente estudadas no Brasil e em outros países desde a década de 50. Este artigo enfatiza três momentos que marcaram o desenvolvimento histórico de nosso conhecimento sobre a biologia destes caramujos: 1 . o acervo antigo acumulado de estudos de laboratório e de campo; 2 . o desenvolvimento de modelos ecológicos quantitativos; 3. o desenvolvimento de metodologia alternativa para o cultivo dos caramujos em condições seminaturais. Palavras-Chave: Ecologia de Moluscos; Biomphalaria sp.; Esquistossomose.

\section{REFERENCES}

ANDRADE, R. M., 1959. Ecologia. Revista Brasileira de Malacologia e Doenças Tropicais, 11: 171-217.

BARBOSA, C. S.; BARBOSA, F. S. \& ARRUDA, F., 1993. Long-term controlled experiment on the competition between two species of Biomphalaria, the snail vectors of Schistosoma mansoni in Northeastern Brazil. Cadernos de Saúde Pública, 9: 170-176.

BARBOSA, F. S., 1956. Some seasonal and climatic factors influencing the life-cycle of Australorbis glabratus and Tropicorbis centimetralis in north-eastern Brazil. Geneva: World Health Organization. (Biology Ecology, 4)

, 1962. Aspects of the ecology of the intermediate hosts of Schistosoma mansoni interfering with the transmission of bilharziasis in north-eastern Brazil. In: Ciba foundation Symposium on Bilharziasis, pp. 23-35, London: J \& A Churchil Ltd. , 1987. Competitive displacement of Biomphalaria glabrata by B. straminea. Memórias do Instituto Oswaldo Cruz, 82: 139-141.
, 1989. Mass migration of juvenile Biomphalaria glabrata snails bred under seminatural conditons. Memórias do Instituto Oswaldo Cruz, 84: 53-56.

BARBOSA, F. S. \& BARBOSA, I., 1958. Dormancy during the larval stages of the trematode Schistosoma mansoni in snail estivating on the soil of natural habitats. Ecology, 39: 763-764.

BARBOSA, F. S.; CARNEIRO, J. \& BARBOSA, I., 1960. Manual de Malacologia Médica. Salvador: Fundação Gonçalo Moniz.

BARBOSA, F. S.; COSTA, D. P. \& ARRUDA, F., 1983. Competitive interactions between species of freshwater snails. I Laboratory Ia. General methodoloy. Memórias do Instituto Oswaldo Cruz, 78: 335-341. , 1985. Competitive interactions between species of fresh-water snails I. Laboratory Ic. Comparative survival of Biomphalaria glabrata and B. straminea kept out of water. Memórias do Instituto Oswaldo Cruz, 80: 155-157.

BARBOSA, F. S. \& DOBBIN, J. E., 1952. Effects of the dry season on Australorbis glabratus. Publicações Avulsas do Instituto Aggeu Magalhães, 1: 145-148.

BARBOSA, F. S. \& OLIVIER, L., 1958. Studies on the snail vectors of bilharziasis mansoni in north-eastern Brazil. Bulletin of the World Health Organization, 18: 895-908.

BARBOSA, F. S.; SANCHESZ, D.; BARBOSA, C. S. \& ARRUDA, F., 1992. Dynamics of snail populations of Biomphalaria glabrata and B. straminea under semi-natural conditions. Cadernos de Saúde Pública, 8: 157-167.

BARBOSA, F. S. \& SILVA, G. M., 1951. Curvas de crescimento de Astralorbis glabratus e sua aplicação à epidemiologia e à profilaxia da esquistossomose. Publicações Avulsas do Instituto Aggeu Magalhães, 1: 35-41.

BARLOW, C. H., 1933. The effect of "winter rotation" of water upon snails involved in the spread of schistosomiasis in Egypt. American Fournal of Hygiene, 17: 724-722.

BARLOW, C. H. \& MUENCH, H., 1951. Life span and monthly mortality rate of Bulinus truncatus and Planorbis boissyi, the intermediate bosts of Schistosomasis in Egypt. Fournal of Parasitology, 37: 165-173. 
BRUMPT, E., 1941. Observations biologiques concernant Planorbis (Australorbis) glabratus, hôte nitermediaire de $S$. mansoni. Annales de Parasitologie Humaine et Comparée, 18: 0945.

COUTINHO, A. B.; GOUVEIA, L. \& LUCENA, D. T., 1940. Investigação em torno da epidemiologia da esquistossomose mansônica em Pontezinha e Vitória, Estado de Pernambuco, Brasil. Memórias do Instituto Oswaldo Cruz, 35: 207-230.

DAZO, B. C.; HAIRSTON, N. G. \& DAWOOD, I. K., 1966. The ecology of Bulinus truncatus and Biomphalaria alexandrina and its implication for the control of bilharzia in the Egypt-49 project area. Bulletin of the World Health Organization, 35: 339-356.

HAIRSTON, N. G.; HUBENDICK, B.; WATSON, M. \& OLIVIER, L. J., 1958. An evaluation of thechniques used in estimating snail populations. Bulletin of the World Health Organization, 19: 661-672.

JOBIN, W. R. \& MILCHELSON, E. H., 1967. Mathematical simulation of an aquatic snail population. Bulletin of the World Health Organization, 37: 657-664.

JORDAN, P. \& WEBBE, G., 1969. Human Schistosomiasis. Springfield: Charles C. Thomas.

JURBERG, P.; SCHALL, V. T.; BARBOSA, J. V.; GATTI, M. J. \& SOARES, M. S., 1987. Behavior of Biomphalaria glabrata, the intermediate host snail of Schistosoma mansoni, at different depths in water in laboratory conditions. Memórias do Instituto Oswaldo Cruz, 82: 179-208.

LOUREAU, M. \& BALUKU, B., 1987. Growth and demography of populations of Biomphalaria pfeifferi (Gastropoda, Planordidae) in the laboratory. Fournal of Molluscan Studies, 53: 171-177.

LUTTERMOSER, G. W., 1946. La Campaña Antibilharziana en Venezuela. XII Conferência Sanitária Panamericana, Caracas, Venezuela. (Publicacione, 12)

LUTZ, A., 1918. Caramujos de água doce do gênero Planorbis, observados no Brasil. Memórias do Instituto Oswaldo Cruz, 10: 6582.
MALEK, E. A., 1958. Factors condicioning the habitat of Bilharziasis intermediate hosts of the family Planorbidae. Bulletin of the World Health Organization, 18: 785-818.

OLIVIER, L. \& BARBOSA, F. S., 1954. Survival and weight loss of Australorbis glabratus from Pernambuco, Brazil, when kept out of water at various relative humidities. Fournal of Parasitology, 40: 36-37.

, 1955a. Seasonal studies on Australorbis glabratus Say from two localities in eastern Pernambuco, Brazil. Publicações Avulsas do Instituto Aggeu Magalhães, 4: 79-103. , 1955b. Seasonal studies on Tropicorbis centimetralis in notheastern Brazil. Publicações Avulsas do Instituto Aggeu Magalhães, 4: 105-115.

OLIVIER, L. \& SCHNEIDERMAN, M., 1956. A method for estimating population density of aquatic schistosoma vectors. Experimental Parasitology, 5: 109-117.

PARAENSE, W. L., 1955. Um aspecto da ecologia do Australorbis glabratus que favorece a reinfestação dos criadouros. Revista do Serviço Especial de Saúde Pública, 7:573-581.

PARAENSE, W. L., 1957. Apertural lamellae in Australorbis glabratus. Procedings of the Malacological Society of London, 32 (part 4): 175-179.

PERLOWAGORA-SZUMLEWICZ, A., 1958. Studies on the biology of Australorbis glabratus, schistosoma-bearing Brazilian snail. Revista Brasileira de Malariologia e Doenças Tropicais, 10: 459-529.

PIERI, O. S., 1985. Studies on the Host Snails of Schistosomiasis from Northeast Brazil, with Special Reference to Diapause in Biomphalaria glabrata (Say). Ph.D Thesis, Sussex: University of Sussex.

PIERI, O. S.; RAYMUNDO, J. S. \& JURBERG, P., 1980. Estudos sobre o comportamento dos planorbídeos: II Enterramento de Biomphalaria glabrata (Say, 1818) como meio de proteção contra a dessecação. Memórias do Instituto Oswaldo Cruz, 75: 83-88.

REY, L., 1956. Contribuição para o Conhecimento da Morfologia, Biologia e Ecologia dos Planorbídeos Brasileiros Transmissores da Esquistossomose. Tese de Doutorado, São Paulo: Universidade de São Paulo. 
RICKLEFS, R. W., 1984. Ecology. New York: Chiron Press Inc.

SCOTT, S. A., 1940. Venezuelan snails of the genus Australorbis. Notulae Naturae, Philadelphia, $\mathrm{n}^{\circ} 54$.

, 1942. La epidemiologia de la schistosomiasis en Venezuela. Revista de Sanidad y Assistencia Social, 7: 771-776.

SILVA, G. M., 1951. Formação das espiras de planorbídeos e suas aplicações. Gênero Autralorbis. Publicações Avulsas do Instituto Aggeu Magalhães, 1: 46-59.

STURROCK, R. F., 1973. Field studies on the transmission of Schistosoma mansoni and on the bionomies of its intermediate host, Biomphalaria glabrata, on St. Lucia, West Indies. International fournal of Parasitology, 3: 175-194.

STURROCK, R. F. \& STURROCK, B. M., 1970. Observations on some factors affecting the growth rate and fecundity of Biomphalaria glabrata (Say). Annals of Tropical Medicine and Parasitology, 64: 349-355.
THOMAS, J. D. \& BENJAMIN, M., 1974. The effects of population density on growth and reproduction of Biomphalaria glabrata. Fournal of Animal Ecology, 43: 31-50.

VELOSO, H. P., 1953. Nota preliminar sobre um novo método de aplicação dos moluseicidas no combate à esquistossomose. Publicações Avulsas do Instituto Aggeu Magalhães, 2: 47-59.

WEBBE, G., 1965. Transmission of Bilharziasis: I some essential aspects of snail population dynamics and their study. Bulletim of the World Health Organization, 33: 147-153.

WOOLHOUSE,M.E.J., 1989. On theinterpretation of age-prevalence curves for schistosome infections of host snails. Parasitology, 99: 4756.

WHO (World Heath Organization), 1957. Study Group on the Ecology of Intermediate Snail Hosts of Bilharziasis. Geneva: WHO. (Technical Report Series, 120). 